\title{
INCORPORATING STUDENT VOICE IN THE TRANSFORMATION PROCESS
}

\author{
S.Anusha ${ }^{1}$, N.Swetha Reddy ${ }^{2}$ \\ ${ }^{1}$ (Ph.D) , Asst.professor, ${ }^{2}$ M.Tech ,Asst.professor \\ ${ }^{1,2}$ K.G. Reddy College of Engineering and Technology \\ ${ }^{1}$ anusha@kgr.ac.in, ${ }^{2}$ nswetha49@gmail.com
}

\begin{abstract}
The voices of students have been missing from the discussion of educational change and the change process. Students are the key stakeholders in the change process. Educators and policymakers need to think of students as the potential beneficiaries of change. We rarely think of students as participants in a process of change and organizational life. Additionally, there are many who believe that students are not capable of making informed decisions. Student voice is important to foster in our classroom because learning becomes more memorable, and students develop research and leadership skills which helps them in building their career. This paper argues that students voice is important in development of educational institution, nation and also to make the student as a perfect confident individual. This paper describes the importance of considering the student voice in classroom and as well as college and how it effectively changes the college and classroom environment. It also gives a clear idea of the methods that can be implemented to involve students in different activities and transform them as a student who can face any challenge and achieve success.
\end{abstract}

Key words: student voice, educational change, stake holders, research

\footnotetext{
S.Anusha ${ }^{1}$

(Ph.D) , Asst.professor,

K.G. Reddy College of Engineering and Technology, anusha@kgr.ac.in
}

\section{INTRODUCTION:}

The term "student voice" refers to the input and perspectives of students, and describes how their voices and actions make the teaching livelier through developing their own questions, researching on the topics and become more involved in their education. With this involvement comes empowerment, as students are able to use their knowledge to contribute to the greater community. "What would happen if we treated the student as someone whose opinion mattered in the introduction and implementation of reform in colleges".

This discussion was started over a decade ago, and research is only beginning to highlight a change in the role that students play in colleges.

\section{INVOKING STUDENTS VOICE IN COLLEGE}

In practice there are four dimensions to pupil involvement:

1. Student involvement in college and community development

2. Students as researchers and co-enquirers

3. Student feedback on teaching and learning

4. Students as peer-tutors

\section{A. Student involvement in college and community development:}

Student's participation in extracurricular activities provides opportunities for students to apply classroom knowledge to real world settings and develops skills that will assist in the practical realities of living after graduation. The added supplement of extra circular activity involvement such as that found in college student organization participation can be a significant factor in student's college experience.

Students involved in organizations gave more meaning to their college experience and thus have significantly greater levels of interdependence, education 
plans, career plans, and life style plans. When students were exposed to other achievement oriented students were able to acquire personal resources such as interpersonal skills, self confidence, and specialized knowledge that encourage the realization of goals and aspirations. Involvement in college student organizations could increase students understanding of their abilities and limitations in their education environment. Thus extra circular activity participation could be an important facet in a student's college experience in that such participation seems to be an effective means of stimulating personal development.

\section{B. Students as researchers and co-enquirers}

All undergraduate students in all higher education institutions should experience learning through, research and inquiry. In undergraduate research, students learn and are assessed in ways that come as close as possible to the experience of academic staff carrying out their disciplinary research. There are four ways of engaging students in research and inquiry.

1. Spend the first half of a lecture outlining a research problem and setting it in a theoretical context.

2. Seamlessly went on to outline some of the different methods and techniques that might be used to investigate the research question.

3. Send students in small groups to the library to undertake a literature-based investigation of the research problem and how it had been addressed.

4. Discuss with the students what research they have done on the topic, the previous week when they visited the library and present that in front of the other students as a team which helps them to improve their communication, confidence and also can be a good team player which will help them in the corporate career.

\section{Student feedback on teaching and learning:}

Students are our key witnesses in the task of identifying changes in and are likely to enhance the quality of their learning. Students benefit in their learning from receiving our comments on their papers and assignments, we may find it beneficial in improving our teaching to receive feedback from our students. The more information that we gather about our teaching the more we can make informed changes that will be beneficial both to our students and to us as we develop as a teacher.

There are several sources of information that we can use: Student feedback ,self evaluation ,peer observation , viewing a video tape of our teaching, and consultation with a staff member from our department. Whatever form of feedback we choose to receive from our students it is useful to get someone else to help us to assess the comments and discuss different possibilities of responding to suggestions made by the students. The instructors who received student ratings in conjunction with counseling that provided encouragement and suggested alternative teaching strategies tended to change their classroom behaviors more than did those who received only student ratings.

\section{Students as peer-tutors}

A peer tutor is anyone who is of a similar status as the person being tutored. In undergraduate institution this would usually be other undergraduates, as distinct from the graduate students who may be teaching the writing classes, There are some basic rules to establishing our peer tutoring program, the "key to success" is a clear objective. Thorough planning and evidence gathering activities will contribute to substantiation of the decisions you will make. There are many benefits for both the peer tutor and tutee in this relationship, one aspect of this is that the tutor can establish a rapport with the tutee in a way that a teacher cannot. A peer tutor may have taken the same class recently, or have taken similar classes.

Because the peer tutor is seen by the tutee as being more at their own level, advice given by the tutor may be accepted more readily than advice from a teacher. Another key reason for this is that a peer tutor does not give any grade on the paper, whereas a teacher serving in a tutor role may still be perceived as someone who grades papers.

Peer tutors can be trained through on-the-job training, as well as through formal workshops. New tutors can be paired with more experienced tutors for their first few tutorials, and after the tutors are satisfied that the new tutors can operate alone they can give one-on-one tutoring. A key aspect of tutor training is the reflection on tutorials with other tutors. This reflection looks at what could have gone better as well as the tutor's progress in giving tutorials.

In higher education tutorial settings, the benefits of peer tutoring programs also extend to class tutors. Using grounded theory techniques, it was found that the following five themes underlie their experiences: role exploration, sharing responsibility, regulation of the peer tutored groups, harnessing the peer tutors' role, and community.

\section{III.STUDENT VOICE IN CLASS ROOM}

Student voice is important to foster in our classroom because learning becomes more memorable, and 
students develop research and leadership skills that will follow them beyond school. To get started incorporating more student voice in our classroom use this four-step process.

\section{A. Inclusion}

When students feel that they matter and are included in the classroom community, they are much more likely to open up and share their perspectives.

Although much of what we focus on in the classroom is academic, social and emotional learning plays an integral part in student success. Send students a motivational message or congratulate them on their work can go a long way. Sometimes send messages to parents, so students can feel supported both in the classroom and at home. Praise students for their hard work and to get them excited for the next day's lesson. Students will be more enthusiastic when they know that their contributions are valued every day.

\section{B. Integration}

Begin to integrate student voice into our daily lessons by creating more opportunities for students to contribute. This can come in the form of whole classroom discussion, small group activities, input on writing activities, and more. Take feedback to have students vote on different writing prompts, project options, or activities. Hear students' perspectives wherever they are even after they leave the classroom.

\section{Transformation}

At the transformational level, teachers can draw on student input to shape curricular goals for the class. Have students develop their own questions to drive learning. What do they want to know about the topic the class is studying? Do they have other related interests within the subject that they want to explore? Hands-on investigations make students a part of learning and lead them to discovery. Brainstorm a KWL chart K-W-L Chart, which tracks what a student knows (K), wants to know (W), and has learned (L) about a topic, can be used before, during, and after research projects. Variation with our students and use group mails to send student-driven questions after class. We can even send a Video Clip of students asking questions as well. Students will come to class each day with new discoveries to share.

\section{Empowerment}

Student empowerment enables students to use their knowledge to contribute to the classroom and greater outside community. When students feel comfortable sharing their voices, they grow into positions of leadership. Empower our students to use their knowledge to educate the community about a particular topic, or tutor students from another grade level. Students can bring awareness to issues of social justice, and make a difference for the better.

Use social networking sites to share volunteering opportunities with students, or to get the word out about class fundraisers.

\section{IV.CO-CREATING A RESPONSIVE LEARNING ENVIRONMENT:}

We need to build our classrooms around the voices in the room. Upon reflection, we realized that student voice is much more than their recording on an app and describing their learning, it's on the walls of our classroom, it's in the co-construction of the physical layout and most evident in the inquiry work. In partnerships with students, educators are realizing the potential of the environment to be a third teacher - one that is responsive to student interests, provide[s] opportunities for children to make their thinking visible and then foster[s] learning and engagement student voice and use it to co-create the learning environment, students feel they are an integral part of a learning community, that they matter and that they have something of value to offer.

This empowers them to take responsibility for their own learning, and that of others, and to take risks and explore new ideas. Taking responsibility for learning and that of others is the most authentic opportunity that students can have to develop self-regulation in the classroom. In an environment where educators listen, capture and are responsive to student voice, they have noticed that students believe they are capable and competent to learn.

The below describes what student may "Do","Feel" and "Be" when they are in a responsive learning environment.

\section{A. Do :}

- Participate in issues that matter to them

- Shape and contribute to their learning environment

- Belong in meaningful partnerships

B. Feel:

- Learner autonomy

- Agency

- Self-efficacy

- Collective efficacy

- Respect

- Belonging

- Motivated

- Connected to their environment

C. Be: 
- In the driver seat of their own learning

- Self-regulator

- Curious

- An active citizen

- Engaged

\section{V.STUDENT VOICE CASE STUDIES IN MY COLLEGE}

\section{Case Study1:}

As per the university norms every college will have national level technical fest which is desired to bring out the talent of young engineers. As a part of it with the idea of my students we had started a technical event "ELECTROPEDIA" from electronics and communication department under my guidance. We formed a team went out for sponsorships, campaigned in other colleges, managed their academics and made that event a big success from the past 4 years. They learnt time management, team work, organizing things which is helping them to lead a successful career.

\section{Case Study2:}

As student achievement and development continue to become the key instrument of choice for identifying effective teaching dynamics. I implemented presentations of topics and correcting them to improve their subject knowledge and make them to research on the topic. To improve practical knowledge I introduced small project competition which helps them to increase their practical knowledge.

\section{Case Study 3:}

With the instructions from our higher authorities we had started the concept of peer tutoring in our college where the higher class students tutoring the corresponding juniors. After implementing this plan in our college students performed well in their examinations and gained good percentages. Students got good grip on the subjects which helped them to understand subjects easily in the next semesters.

\section{Case Study 4:}

To change the class room environment active students voices are need to be considered in effective manner. Whether they understand the subject or if they have any suggestions we have the concept of student feed back form which is available in the website. Students can express their views or any modifications need to be taking for classroom become active. If there is any problem with the teacher so that the teacher will know the problem and will take that step accordingly.

\section{VI.CONCLUSION:}

Students are the backbone of any society and nation. The educational institutions, country and the nation should have immense faith in students. We always listen to the proverb "India is a developing country ", if students are given a chance to raise their voice in every aspect and share their ideas ,in few years India will definitely become a developed nation. Current research is beginning to suggest that student voice, when it involves students having a genuine say in their learning, has served as a catalyst for change in schools and colleges. Positive outcomes include: helping to improve teaching and learning; improving teacher-student relationships; increasing student engagement with their learning; and raising student self-esteem and efficacy. student voice activities can create meaningful experiences for youth that help to meet fundamental development needs and gain respect for the nation.

\section{ACKNOWLEDGMENT}

We are very thankful for giving this opportunity to write this paper and thankful to my institute for supporting to execute these activities in the college as well as in class room.

\section{REFERRENCES:}

1. Peacock, A. (2011). Beyond Assessment Levels: Reaching for new heights in primary education. Education Review, 23(2), 14-22. Rinaldi, C. (2004).

2. The relationship between documentation and assessment. The Quarterly Periodical of the North American Reggio Emilia Alliance, 11(1). Shanker, S. (2013).

3. Calm, alert, and learning: Classroom strategies for self-regulation. Toronto, ON: Pearson Canada

4. "Student Voice Transforming Relationships" Capacity Building Series SECRETARIAT SPECIAL EDITION \# 34 September 2013 ISSN: 19138482 (Print) ISSN: 19138490 (Online)

5. http://blog.remind.com/empower-student-voice/

6. Calkins, Lucy McCormick (1986). The art of teaching writing. Portsmouth, N.H.: Heinemann.

7. ED440049 1999-11-00 Incorporating Student Voice into Teaching Practice. ERIC Digest. 